\title{
Comparative Studies on Chemical Composition of Two Conventional Bred and One Genetically Engineered Plum-Fruits
}

\author{
Otilia BOBIŞ ${ }^{1}$, Ioan ZAGRAI ${ }^{2}$, Victorița BONTA ${ }^{1}$, Luminiţa ZAGRAI ${ }^{2}$, Liviu A. MĂRGHITAŞ ${ }^{3}$, Daniel S. \\ DEZMIREAN ${ }^{3}$, Claudia PAȘCA ${ }^{3}$, Adriana URCAN ${ }^{3 *}$ \\ ${ }^{1}$ Life Science Institute "King Michael I of Romania", University of Agricultural Sciences and Veterinary \\ Medicine - 400372, Cluj-Napoca, Mănăștur, 3-5, România \\ ${ }^{2}$ Fruit Research and Development Station Bistrița - 420127, Bistrița, Drumul Dumitrei Nou, 3, România \\ ${ }^{3}$ Faculty of Animal Science and Biotechnologies, University of Agricultural Sciences and Veterinary \\ Medicine - 400372, Cluj-Napoca, Mănăștur, 3-5, România \\ ${ }^{*}$ Corresponding author, e-mail: adriana.urcan@yahoo.com
}

Bulletin UASVM Animal Science and Biotechnologies 74(2)/ 2017

Print ISSN 1843-5262; Electronic ISSN 1843-536X

DOI:10.15835/buasvmcn-asb: 0020

\begin{abstract}
The European plum (Prunus domestica L.) is one of the most important cultivated species among fruit trees in the world, and the dominant in Romania. Regarding the development of new plum cultivars derived from Prunus domestica, the following characteristics are taken into consideration most of the time: high yield performance, good quality fruits and last but not least, the resistance to PPV. "HoneySweet" is a transgenic clone of Prunus domestica transformed with Plum pox virus coat protein gene making it highly resistant to the virus. This study presents preliminary results on the chemical composition of HoneySweet transgenic plum and two conventional ones: Reine Claude d'Althan and Stanley. The most important nutritional factors were determined. HoneySweet had balanced individual carbohydrates content but lower soluble solids in comparison with the two conventional cultivars. Total lipids content in HoneySweet fruits was similar to Stanley, higher than in Reine Claude d'Althan. HoneySweet is distinguished by the highest total protein content. Similar amounts of magnesium and calcium were recorded in the three varieties. Overall, our preliminary results revealed that the quality and nutritional value of "Honey Sweet" genetic engineered plum is in the range of other valuable plum cultivars.
\end{abstract}

Keywords: Chemical composition, Prunus domestica, Plum pox potyvirus

\section{INTRODUCTION}

Among the stone fruits, plum (Prunus domestica L.) is widely distributed in Europe, but also in United States, Japan or China, well adapted to different soils and climatic conditions (Dugalic et al., 2014). The selection of cultivars depends on the local climatic conditions and soil, in order to increase the productivity of respective orchards.

Plum pox virus (PPV) which causes Sharka disease is considered the most devasting pathogen of Prunus species (Cambra et al., 2006). It often produces severe symptoms on fruits and premature droping causing serious yield losses. PPV infection may also induce biochemical modification in fruits affecting thus its quality (Pattantyus and Minoiu, 1983, Zagrai et al., 2002). Therefore, the use of resistant cultivars as the effective strategy to reduce the economical losses caused by PPV is required. Since the paucity of natural resistance has hampered the efforts to control Sharka disease, genetic engineering was used as a complementary aproach to conventional breeding. One transgenic line, C5, subsequently named 'HoneySweet' was developed (Scorza et 
al., 2004) as the first genetically engineered Plum pox virus - resistant plum cultivar (Scorza et al., 2016). This transgenic line is currently grown in a new field trial in Bistrița, making the subject of different studies related to the agronomical and phenotype performance under PPV endemic area and geo-climatic conditions of Romania.

Plums are mostly used for fresh consumption, but also for processing. In Romania, large surfaces are cultivated with different varieties of plum (Tuleu gras, Grase românești, Vinete românești, Stanley, Anna Späth, d'Agen, Vinete de Italia, Reine Claude d'Althan) and the top Romanian products after fruit industrialization is "țuica de prune", a traditional Romanian brandy and "magiun", a DOC European recognized marmalade made from plums, with no added sugar. Due to their nutritive value and high amounts of bioactive compounds, plums are recommended as dietary fruits that should not be missing from our diet, also because of their low calories and many other health promoting compounds such as flavonoids, anthocyanins, carotenoids, minerals (Voća et al., 2009, Walkowiak-Tomczak, 2008).

The determination of maturity for harvest is very important for final fruit quality, storage-life or maximum amount of nutritive and bioactive compounds (García-Marino et al., 2008, Singh et al., 2009, Sudar et al., 2011, Scorza et al., 2013). During the ripening process, biochemical modifications lead to development of characteristic attributes of taste, colour, flavor and firmness. Development of these attributes is a consequence of content changing in some chemical components of the fruit, as a result of their oxidation or contrary, of their biosynthesis. It can be stated that taste modification is given by the changing in the reducing sugars ratio, organic acids and phenolic substances. Fruit firmness modification is a consequence of pectic substances biodegradation. Colour modification is due to biodegradation of chlorophyll pigments and biosynthesis of carotenoid and anthocyanidin pigments. Development of characteristic flavor is due to accumulation of metabolic intermediate compounds, with high degree of volatilization (Burzo et al., 1999). In the maturation process, other biochemical modification may occur, which affect the content in sugars, lipids, proteins, vitamins and other secondary compounds (Nergiz and Yildiz, 1997, Muste, 2008, Sudar et al., 2011,
Milošević and Milošević, 2012a, b, Mubarak et al., 2012).

The aim of the present study was to determine by modern techniques, the nutritional value of HoneySweet fruits and if it chemical composition is in the range of other valuable non genetic modified plum cultivars.

\section{MATERIALS AND METHODS}

Chemicals. Folin-Ciocalteu reagent, gallic acid, naringenin, quercetin standards were obtained from Sigma-Aldrich (St.Louis MO, USA). All other chemicals and solvents were of ultrapure grade.

Samples. Plum samples of three different cultivars were provided by Fruit Research and Development Station Bistrița, Romania, harvested in 2016 in their full ripening stage. Samples were kept in the freezer as fresh fruits, until analysis. For a better extraction of the components, samples were minced in a porcelain mortar. The research has been carried out in Laboratory of Quality Control for Bee Products from Life Science Institute, USAMV Cluj.

Nutritional components. Chemical composition was determined by analyzing water and ash content, acidity, total proteins and lipids, total sugar content and individual sugar spectrum, vitamin $\mathrm{C}$, as well as mineral content. Standard or own developed methods were used for the analysis.

Water content. Water content was determined by drying until constant weight. An amount of $5 \mathrm{~g}$ was weighted (four decimals precision) on a glass and placed at $60^{\circ} \mathrm{C}$ in oven (Binder Germany), for 4 hours. After mentioned period and cooling in exsicator, the samples were weighted and placed again in the oven for another hour. This process is repeated until the difference between two weighters is only on fourth decimal.

Ash content. Ash was also determined gravimetrically, weighing the crucible after calcination. The sample is weighted in a crucible with a precision of $0.0002 \mathrm{~g}$ and burned on open flame until the smoke is developing. Than the crucible is burned on the flame of a gas lamp until the smoke appears. Following this, the crucible is placed in the electric oven at $600^{\circ} \mathrm{C}$ for 4 hours. After this period, the crucible is cooled in an exsicator until room temperature and than is weighted. The operation is repeated until the residue from the crucible looks like a white ash, 
without traces of black material and until constant weight.

Total sugar content ( ${ }^{\circ}$ Brix). Total sugar determination is made easily by refractometer. This is optic equipment that allows measurement of refractive index of liquid substances. For sugar determination, 2-3 drops of fresh squeezed plum juice is placed on the prism of the apparatus, the refractive index and Brix (unit for measuring the sugar content of an aqueous solution) are read. If we want to transform Brix in sugar content: $1^{\circ} \mathrm{Brix}$ $=10.04 \mathrm{~g} /$ liter at $20^{\circ} \mathrm{C}$.

pH and acidity. Content of organic acids is reflecterd in free acidity of organic matrices. Acidity of the samples was determined by titration with $\mathrm{NaOH}$ until equivalence point using automatic titrator Titro Lyne Easy.

Five grams minced sample is mixed with $25 \mathrm{ml}$ ultrapure water and bring to sign at $50 \mathrm{ml}$. The mixture is homogenized and centrifuged. Obtained fíltrate $(25 \mathrm{ml})$ is titrated with $\mathrm{NaOH} \quad 0.1 \mathrm{~N}$ until the equivalent point, using automatic titrator Titroline Easy (Schott, Germany).

Sugar spectrum. Method used for determination of sugar spectrum is high performance liquid chromatography with refractive index detection.

Five grams of homogenized sample is weighted in a Berzelius glass, and $40 \mathrm{ml}$ water is added and placed on a magnetic stirrer. After homogenization, the sample is filtered through filter paper and placed in an $100 \mathrm{ml}$ flask containing $25 \mathrm{ml}$ methanol and than is bring to the sign with water. Before injecting to the HPLC system, the solution is filtered through a Millipore filter $(0.45$ $\mu \mathrm{m})$ and placed in glass vials until analysis.

Operational parameters of chromatographic system were: column: modified Alltima Amino 100Å, $5 \mu \mathrm{m}, 250 \times 4,6 \mathrm{~mm}$; mobile phase flow: 1.3 $\mathrm{ml} / \mathrm{min}$; mobile phase: acetonitrile/water (75/25; $\mathrm{v} / \mathrm{v}$ ); column temperature: $30^{\circ} \mathrm{C}$; injection volume : $20 \mu \mathrm{l}$; separation time: $60 \mathrm{~min}$.

Sugar standard solutions are prepared analoguously to the analyzed sample. They are injected and analysed separately to determine the retention time of each sugar and than in mixture for the calibration curve construction.

Lipid content. Total lipids were determined by extraction with organic solvents using Soxhlet method. Two grams of sample were weighted on filter paper, which will be packed and placed in the paper cartridge. Dry and clean extraction glasses containing 2 boiling stones, will be weighted and together with the cartridge and the solvent $(70 \mathrm{ml}$ n-hexane) will be fixed in PTFE cylinders.

The method is set from the multistat: extraction temperature $140{ }^{\circ} \mathrm{C}$, extraction time $3 \mathrm{~h}$, $25 \mathrm{~min}$, washing $30 \mathrm{~min}$, solvent evaporation in hot air flow $10 \mathrm{~min}$.

After extraction ends, extraction glasses will be placed in the oven at $60{ }^{\circ} \mathrm{C}$, for one hour, to eliminate traces of solvent and after cooling will be weighted and the result were expressed as percent.

Protein content. From the homogenized sample, $1 \mathrm{~g}$ is weighted in paper bags handled with a tweezer so that they are not contaminated with different substances that may contain nitrogen. Paper bags are placed in digestion unit vialse (Buchi Digesion Unit K-424), with 2 Kjeldahl tablets and $20 \mathrm{ml}$ concentrated sulphuric acid (95$98 \%$ ). Digestion lasts $2 \mathrm{~h}$, until the solution turns to green. Distilation is made with Büchi, KjelFlex $\mathrm{K}-360$ unit, every determination is made with a mixture of reagents $\left(50 \mathrm{ml} \mathrm{H}_{2} \mathrm{O}: 90 \mathrm{ml} \mathrm{NaOH}: 60 \mathrm{ml}\right.$ $\mathrm{H}_{3} \mathrm{BO}_{3}$ ). Titration is made with automatic titrator TitroLine Eeasy (Schott), using $0.05 \mathrm{M}$ sulphuric acid for low protein matrices, until pH of 4.65.

Mineral content. Atomic absorption spectrometry is defined as a method for determining the concentration of an element from a sample by measuring radiation absporption in atomic vapours produced by the sample at a specific wavelength, characteristic to the studied element. Increasing the number of atoms from the radius emitted by the hollow cathode lamp increases the amount of light absorbed from the radius, so by measuring the amount of light absorbed, the amount of analyte in the sample can be determined. Obtaining a population of free atoms is one of the main functions of atomic absorption spectrometers. It can be done by analyzing the sample in flame or electrothermal in the graphite furnace.

To determine the levels of $\mathrm{Na}, \mathrm{Mg}, \mathrm{K}, \mathrm{Ca}, \mathrm{Fe}$ from the studied matrix (three varieties of plums) atomic absorption spectrometry was used, with atomization in THGA graphite furnace and Analyst 800 Perkin-Elmer spectrometer with transversal heating. The oven has an electromagnet for magnetic field generation, which will induce the Zeeman Effect, needed for background correction. 
Sample mineralization was made in a Berghof microwawe digestion system MWS-2. Weighted

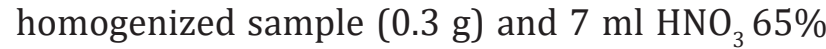
were placed in the special container and sealed. The digestion takes place in 3 steps at 125, 165 and $170^{\circ} \mathrm{C}$ for 10,9 and 1 min respectively. At the end of the program, the resulting solution is transported in plastic tubes and diluted to 125 ml with ultrapure water (Application Report Speedwave MWS-2, Microwave Pressure Digestion, V.4., Berghof Products+Instruments, Germany).

Different dilutions of stock standard solutions: calcium $(2 \mu \mathrm{g} / \mathrm{l})$, iron $(20 \mu \mathrm{g} / \mathrm{l})$, sodium $(4.0 \mu \mathrm{g} / \mathrm{l})$, potassium $(5.0 \mu \mathrm{g} / \mathrm{l})$, magnesium $(1.0 \mu \mathrm{g} / \mathrm{l})$, delivered by Cromatec Plus, România, were used for calibration curve drawing.

Vitamin C determination. Vitamin $\mathrm{C}$ was determined titrimetrically. Chemical methods for determining the vitamin $\mathrm{C}$ are based on its reducing properties. Ascorbic acid is transformed by oxidation in dehydroascorbic acid using different oxidative agents. The determination must be made very quickly, because of the oxidation process. Homogenized plum fruits are weighted (15 g), with $0.01 \mathrm{~g}$ precision, mixed with $10 \mathrm{ml} \mathrm{HCl}$ $2 \%$ and $2.5 \mathrm{~g}$ cuartz sand, for $10 \mathrm{~min}$. The mixture was brought to sign in a $50 \mathrm{ml}$ beaker with $2 \% \mathrm{HCl}$ solution. The suspension was filtered through filter paper and than centrifuged. Ten $\mathrm{ml}$ of the filtrate is placed in an Erlenmayer flask, $30 \mathrm{ml}$ distilled water, $5 \mathrm{ml} \mathrm{KI}, 5 \mathrm{ml} \mathrm{HCl}$ and $1.5 \mathrm{ml}$ starch solution was added. Using $\mathrm{KIO}_{3}$ solution, the sample with reagents was titrated until blue colour appears. The colour has to last $30 \mathrm{sec}$. According to the chemical reaction, one mol of potassium iodide generated 3 mols of iodine which oxidate 3 mols of vitamin $\mathrm{C}$. The content of vitamin $\mathrm{C}$ is calculated according to a specific formula:

Vit $C(\mathrm{mg} / 100 \mathrm{~g})=(\mathrm{Vx} 5 \mathrm{x} 0.352 \times 100) / \mathrm{m}$, where $\mathrm{V}$ is the titration volume of $\mathrm{KIO}_{3} \mathrm{~m}$ - sample mass

\section{RESULTS AND DISCUSSIONS}

Main chemical composition parameters for the analyzed samples is presented in Table 1 . Some of the parameters differ significantly between cultivars, and others are similar regardless of the cultivar, results reported also in the literature studies (García-Marino et al., 2008, Milošević and Milošević, 2012b, Ravelonandro et al., 2013).
For plum samples harvested in 2016, water content lies between $77.11 \%$ (Stanley) and 84.68\% (HoneySweet) (Table 1). This could be seen even before analysis, because the pulp mass of different varieties was very different: Stanley $<$ Reine Claude d'Althan < HoneySweet varieties. Implicitly, the highest amount of dry weight was registered in Stanley variety, and the lowest HoneySweet variety.

Ash content of HoneySweet variety was also the lowest compared to the other two varieties (Stanley and Reine Claude d'Althan)(Table 1).

Dry weight for different varieties of HoneySweet cultivar (Ravelonandro et al., 2013) lies between 8.65 and $10.75 \%$, lower than in our study (15.32\%) and lower values for Stanley variety (13.35\%), compared to our results (22.89\%). Dry weight is influenced by cultivar and also by climatic conditions (temperature, rainfall and landscape), results from 15.86 to $22.71 \%$ were obtained in different years and different varieties of plums (Dugalic et al., 2014).

Total amount of sugars expressed as ${ }^{\circ}$ Brix, presented similar values for all the varieties (Table 1), because the fruits were harvested in their optimal period of ripeness, depending of variety. Thus, Reine Claude d'Althan variety had slight higher amount of total sugars compared to HoneySweet and Stanley vartieties, confirmed later by HPLC analysis also. Sample $\mathrm{pH}$ is acidic (3.40 - 3.57), presenting closer values for all varieties, similar to literature studies (Ravelonandro et al., 2013).

The study of Ravelonandro et al. (2013), show an amount of $10.00-11.17 \%$ soluble solids in five HoneySweet variant, lower than in our study, and an amount of $14 \%$ for Stanley variety (also lower than in our study).

Similar results to ours were obtain by Milošević and Milošević (2012b) for Stanley variety and different F1 hybrids of Stanley, regarding soluble solids, titratable acidity and $\mathrm{pH}$, but lower SS/TA ratio (ripeness index) (13.6 - 14.52) compared to our results (19.03) (Table 1).

Content of fructose, glucose and sucrose for the analyzed samples is presented in Fig. 1

In the samples prepared according to the described protocol, fructose ( $\mathrm{min} 8.1$ ), glucose ( $\mathrm{min}$ 9.5) and sucrose (min 15.8) were identified (Fig. 1). The highest amount of sugars was quantified in Renclod Althan variety (sum of fructose, glucose 
Tab. 1. Chemical characteristics of analyzed plum varieties. Results are mean of three independent determinations \pm standard deviation

\begin{tabular}{cccc}
\hline Parameter/Plum variety & Reine Claude d'Althan & HoneySweet & Stanley \\
\hline Water content (\%) & $83.02 \pm 0.14$ & $84.68 \pm 0.30$ & $77.11 \pm 0.16$ \\
\hline D.W. (\%) & $16.98 \pm 0.14$ & $15.32 \pm 0.30$ & $22.89 \pm 0.16$ \\
\hline Ash content (\%) & $0.23 \pm 0.01$ & $0.19 \pm 0.01$ & $0.20 \pm 0.01$ \\
\hline Ash content (\% D.W.) & $3.89 \pm 0.02$ & $2.94 \pm 0.10$ & $4.68 \pm 0.24$ \\
\hline Soluble solids ( ${ }^{\circ}$ Brix) & $17.4 \pm 0.12$ & $15.7 \pm 0.21$ & $15.8 \pm 0.23$ \\
\hline pH & 3.43 & 3.57 & 3.40 \\
\hline Titratable acidity (\%) & $0.71 \pm 0.02$ & $1.48 \pm 0.05$ & $0.83 \pm 0.01$ \\
\hline $\begin{array}{c}\text { SS/TA ratio (ripeness } \\
\text { index) }\end{array}$ & 24.51 & 10.61 & 19.03 \\
\hline
\end{tabular}

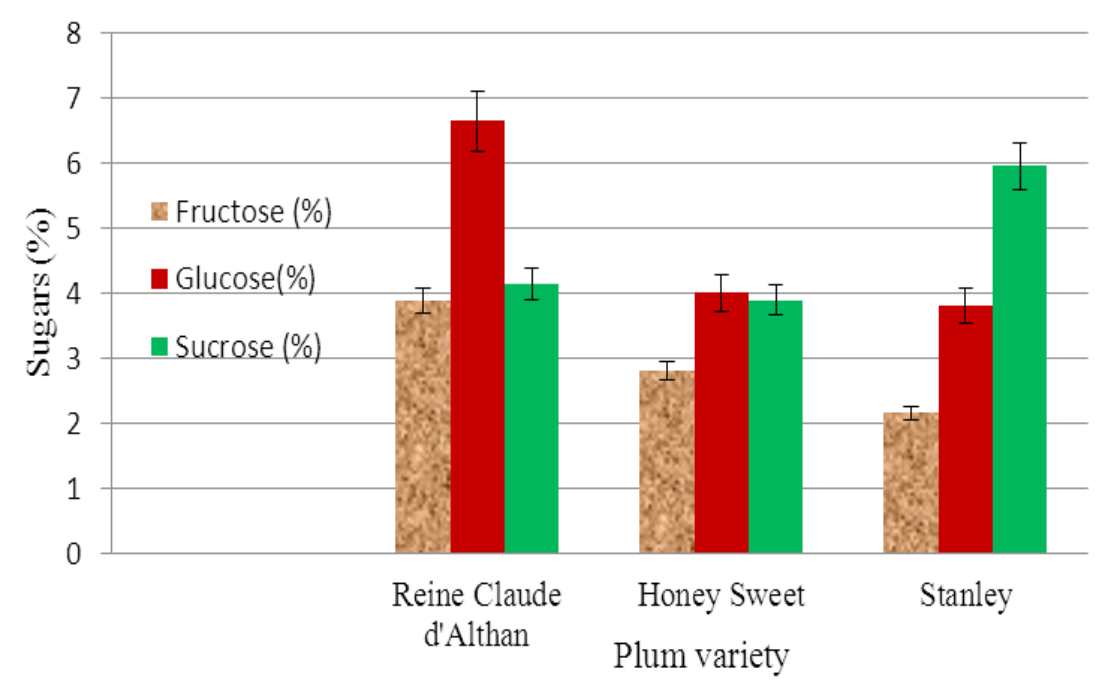

Fig. 1. Fructose (\%), glucose (\%) and sucrose content (\%) in the three plum varieties

and sucrose), even if higher amount of sucrose was obtain in Stanley variety (Fig.1).

Regarding the literature data, similar amounts of glucose and fructose were obtain for Stanley variety and its hybrids (Milošević and Milošević, 2012b), but higher amounts of sucrose were obtained in our study for this plum variety. Ravelonandro et al. (2013), obtained lower amounts of simple sugars for HoneySweet, Reine Claude d'Althan and Stanley varieties $(8.25,8.84$ and $10.48 \mathrm{mg} / 100 \mathrm{~g}$ respectively), compared to the results obtained in our study.

Standard mixture used in the analysis, contained also maltose, isomaltose, turanose, trehalose, erlose and melezitose (Figure 2). In another determination, standard of lactose was used to see if our samples contain also this sugar. Above mentioned simple sugars were not identified in the plum samples.
By excellence, plums are not rich in lipids or proteins. The content of these classes of compounds are presented in Figure 3.

Reine Claude d'Althan variety presented the lowest amount of total lipids ( $0.75 \%$ ), and Stanley variety the highest (1.5\%). According to different literature studies (Walkowiak-Tomczak, 2008, Ravelomandro et al., 2013), the fat content in plums lies between 0.1 şi $0.3 \%$. Our results show higher amounts of total lipids, compared to same cultivars analyzed by different authors (Milošević and Milošević, 2012a, Ravelonandro et al., 2013).

Protein content was similar to literature data (Ravelonandro et al., 2013), the highest amount of nitrogen, converted to protein was obtained in HoneySweet variety $(1.418 \%)$, the lowest being registered for Reine Claude d'Althan $(0.665 \%)$.

Same plum cultivars present, in the study of Ravelonandro et al. (2013), protein values 


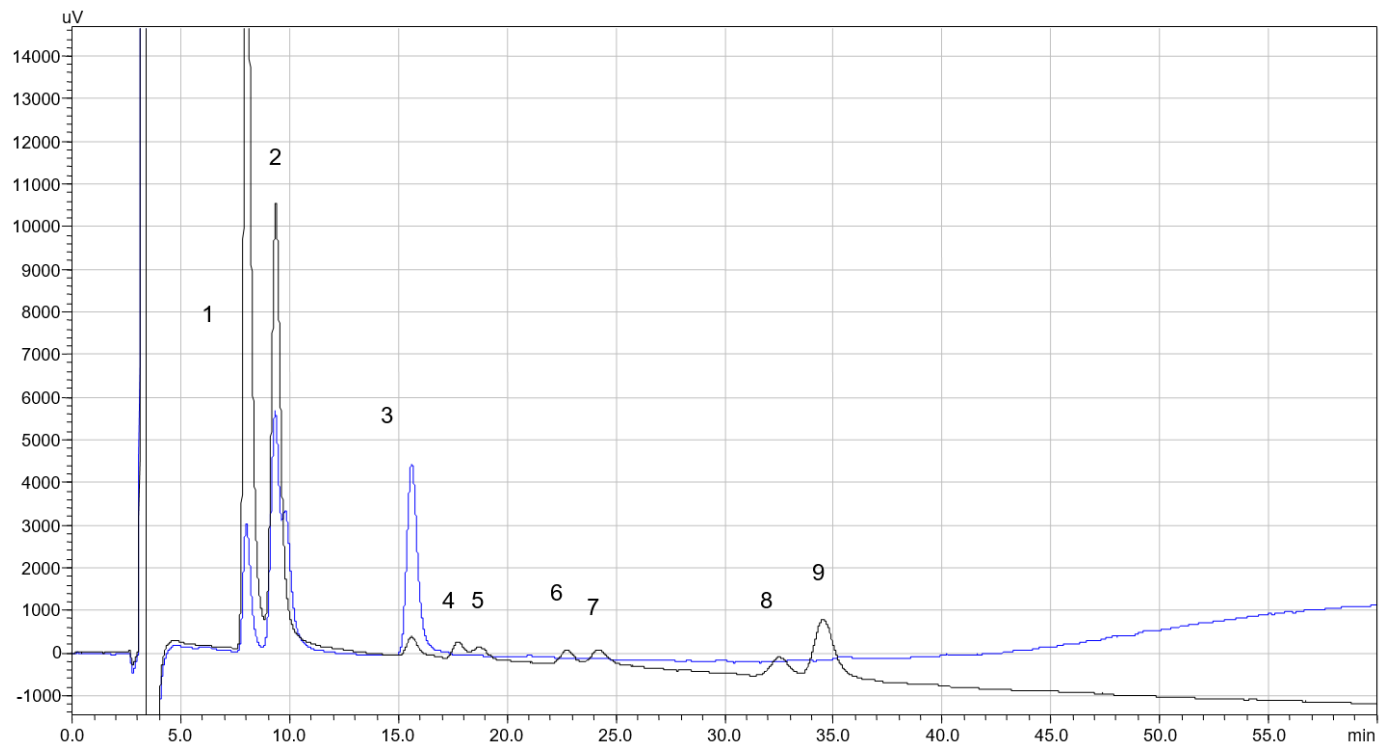

Fig. 2. Standard mixture chromatogram for HPLC sugar determination (black) and HoneySweet variety (blue). Peak identification: 1-fructose, 2-glucose, 3-sucrose, 4- maltose, 5-izomaltose, 6- turanose, 7-trehalose, 8- erlose and 9-melezitoze

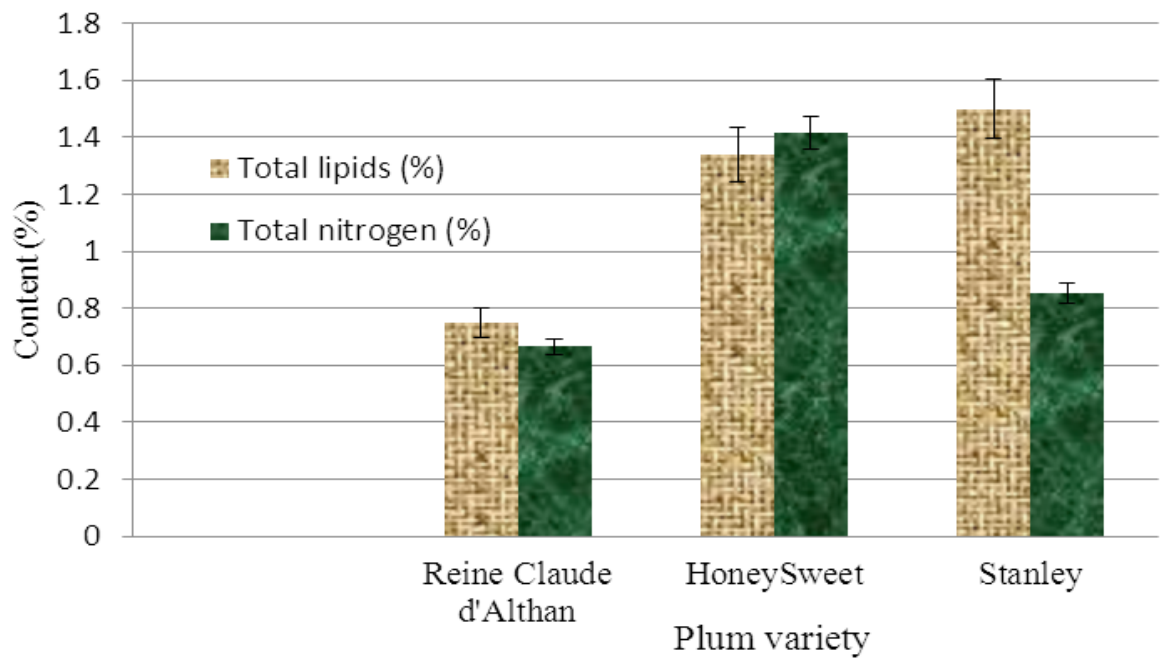

Fig. 3. Total lipids and total protein content in three plum varieties

of $1.03 \%$ (HoneySweet), $0.54 \%$ (Stanley) and $0.72 \%$ (Reine Claude d'Althan). As stated before, regarding other chemical components, year of production, climatic and geographical conditions may influence the values obtained even for the same varieties or cultivars.

Nergiz and Yildiz (1997), analyzing different plum varieties (many of them produced and cultivated in Romania), obtained similar concentrations of total proteins.

Mineral content of plums was determined after construction of each calibration curve $(\mathrm{Mg}$, $\mathrm{Fe}, \mathrm{Ca}, \mathrm{Na}, \mathrm{K}$ ) and are presented in Table 2.
Plum varieties analyzed in this study, revealed high amounts of calcium and potassium. Calcium content was similar in all three cultivars (5.70 $5.75 \mathrm{mg} / \mathrm{kg}$ ), potassium being quantified in high amounts in Reine Claude d'Althan variety $(3.36 \mathrm{mg} /$ $\mathrm{kg}$ ), followed by HoneySweet $(2.65 \mathrm{mg} / \mathrm{kg}$ ) and the lowest value in Stanley cultivar $(1.93 \mathrm{mg} / 100 \mathrm{~g})$. Also high amounts of iron were quantified in the samples. It was strange to see that Stanley cultivar presented a very high amount of iron, which leads to the highest amount of identified minerals from the three studied varieties. The content of iron is higher than the one obtained by Ravelonandro et 
Tab. 2. Concentration of vitamin C, macro and microelements in analyzed plums. Results are mean of three independent determinations \pm standard deviation

\begin{tabular}{cccc}
\hline Partameter/Plum variety & Reine Claude d'Althan & HoneySweet & Stanley \\
\hline Vitamin C (mg/100g) & $3.14 \pm 0.02$ & $8.54 \pm 0.05$ & $9.61 \pm 0.03$ \\
\hline $\mathrm{Mg}(\mathrm{mg} / \mathrm{kg})$ & $0.112 \pm 2.12$ & $0.107 \pm 0.11$ & $0.126 \pm 0.74$ \\
\hline $\mathrm{Fe}(\mathrm{mg} / \mathrm{kg})$ & $2.867 \pm 18.00$ & $1.919 \pm 4.24$ & $18.019 \pm 79.42$ \\
\hline $\mathrm{Ca}(\mathrm{mg} / \mathrm{kg})$ & $5.747 \pm 68.83$ & $5.704 \pm 8.47$ & $5.769 \pm 5.29$ \\
\hline $\mathrm{Na}(\mathrm{mg} / \mathrm{kg})$ & $0.710 \pm 23.30$ & $0.542 \pm 11.44$ & $0.714 \pm 44.47$ \\
\hline $\mathrm{K}(\mathrm{mg} / \mathrm{kg})$ & $3.364 \pm 58.24$ & $2.649 \pm 20.13$ & $1.936 \pm 8.47$ \\
\hline Total minerals & 12.799 & 10.922 & 26.564 \\
\hline
\end{tabular}

al. (2013). The same study reported quantities of below $0.1 \%$ of calcium, magnesium and sodium, without specifying the exact amount.

Vitamin C, determined by titrimetric method, was in accordance with literature studies on the same varieties of plums, the highest amount being found for Stanley variety $(9.61 \mathrm{mg} / 100 \mathrm{~g})$, closely followed by HoneySweet $(8.54 \mathrm{mg} / 100 \mathrm{~g})$ and lower for Reine Claude d'Althan $(3.14 \mathrm{mg} / 100 \mathrm{~g})$. Similar values were obtained by Ravelonandro et al. (2013) for the same cultivars (Stanley 9.5 $\mathrm{mg} / 100 \mathrm{~g}$, HoneySweet $8.0 \mathrm{mg} / 100 \mathrm{~g}$ and Reine Claude d'Althan $2.5 \mathrm{mg} / 100 \mathrm{~g}$ ).

\section{CONCLUSION}

The samples analyzed from physico-chemical point of view, presented valuable characteristics from nutritional point of view. Comparing the three varieties, we can conclude:

The highest amount of sugars was highlighted on Reine Claude d'Althan variety, with highest fructose content. HoneySweet variety revealed an equilibrate amount of individual sugars.

Total lipid content was higher in Stanley and HoneySweet varieties, meanwhile Reine Claude d'Althan has the lowest amount of lipid content.

HoneySweet cultivar presented the highest amount of proteins, followed by Stanley and in the end Reine Claude d'Althan.

High amounts of calcium, potassium and iron were quantified in the analyzed samples, and lower amounts of magnesium and sodium, comparable to the literature studies

High amounts of vitamin $C$ were present in Stanley and HoneySweet cultivars, and lower in Reine Claude d'Althan

Aknowledgement: Financial support was granted by the project ADER 413/2015, developed through the Ministery of Agriculture and Rural Development, Romania. The authors declare no conflict of interests.

\section{REFERENCES}

1. Burzo I, Toma T, Olteanu I, Dejan L, Delian D, Hoza D (1999). Fiziologia plantelor de cultură, Firma Editorial Poligrafică Tipografia Centrală, Chişinău, Moldova.

2. Cambra M, Capote N, Myrta A, Llácer G (2006). Plum pox virus and estimated costs associated to sharka disease. Bulletin OEPP/EPPO 36: 202-204.

3. Dugalic K, Sudar R, Viljevac M, Josipovic M, Cupic T (2014). Sorbitol and sugar composition in plum fruits influenced by climatic conditions, Journal of Agriculture, Science and Technology, 16, 1145-1155.

4. García-Marino N, de la Torre F, Matilla AJ (2008). Organic acids and soluble sugars in edible and nonedible parts of Damson Plum (Prunus domestica L., subsp.insititia cV Syriaca) fruits during development and ripening, Food Science and Technology International, 14, 187-193.

5. Milošević T, Milošević N (2012a). Factors influencing mineral composition of plum fruits, Journal of Elementology, 3, 453-464.

6. Milošević T, Milošević N (2012b). Main physical and chemical traits of fresh fruits of promising plum hybrids (Prunus domestica) from Carak (Western Serbia), Romanian Biotechnological Letters, 17(3), 7358-7365

7. Mubarak A, Swinny E, Ching SYL, Jacob SR, Lacey K, Hodgson JM, Croft KD, Considine MJ, (2012). Polyphenol Composition of Plum Selections in Relation to Total Antioxidant Capacity, Journal of Agricultural and Food Chemistry, 60, 10256-10262.

8. Muste S (2008). Materii prime vegetale în industria alimentara, AcademicPress Publishing house, ClujNapoca, Romania.

9. Negriz C, Yildiz H (1997). Research on chemical composition of some varieties of European plums (Prunus domestica) adapted to the Aegean district of Turkey, Journal of Agricultural and Food Chemistry, 45, 2820-2823.

10. Pattantyus K, Minoiu N (1983). Modificari biochimice induse de varsat (plum pox) la prun. Din contributia cercetarii stiintificela producerea materialului saditor pomicol liber de viroze, 133-149. 
11. Ravelonandro M, Scorza R, Polak J, Callahan A, Krska B, Kundu J, Briard P (2013). „Honey Sweet” Plum - a valuable genetically engineered fruit-tree cultivar, Food and Nutrition Science, 4, 45-49.

12. Scorza R, Ravelonandro M, Callahan AM, Cordts JM, Fuchs M, Dunez J (1994) Transgenic plums (Prunus domestica L.) express the plum pox virus coat protein gene. Plant Cells Reproduction, 14: 18-22.

13. Scorza R, Callahan A, Dardick C, Ravelonandro M, Polak J, Malinowski T, Zagrai I, Cambra M, Kamenova I (2013). Genetic engineering of Plum pox resistance: "Honey Sweet" plum - from concept to product, Plant Cell Tissue and Organ Culture, 115, 1-12.

14. Scorza R, Ravelonandro M, Callahan A, Zagrai I, Polak J Malinowski T, Cambra M, Levy L, Damsteeght Y, Krska B, Cordts J, Gonsalves D, Dardick C (2016). HoneeSweet (C5), the First Genetically Engineered Plum pox virus - resistant Plum (Prunus domestica L.) Cultivar. HortScience 51 (5): 601- 603.

15. Singh SP, Singh Z, Swinny EE (2009). Sugars and organic acids in Japanese plums (Prunus salicina Lindell) as influenced by maturation, harvest date, storage, temperature and period, International Journal of Food Science and Technology, 44(10), 1973-1982.

16. Sudar R, Jurković Z, Dugalić K, Tomac I, Jurković V, Viljevac $M$ (2011). Sorbitor and sugar composition of plum fruit during ripening, Proceedings of the $46^{\text {th }}$ Croatian and $6^{\text {th }}$ International Symposium on Agriculture, Opatija, Croatia, 1067-1071.

17. Voća S, Galić A, Šindrak Z, Dobričević N, Pliestić S, Družić J (2009). Chemical composition and antioxidant capacity of three plum cultivars, Agriculturae Conspectus Scientificus, 74(3), 273-276.

18. Walkowiak-Tomczak D (2008). Characteristics of plums as a raw material with valuable nutritive and dietary properties - A review, Polish Journal of Food and Nutrition Sciences, 58(4), 401-405.

19. Zagrai I, Maxim A, Florian V, Zagrai Luminița, Oroian I, Țigăuan N (2002). Modificări biochimice induse de virusul plum pox în fructe la diferite soiuri, clone și hibrizi de prun. Revista de Protectia Plantelor Transilvania, ClujNapoca, Anul XII, nr. 45: 100-110. ISSN-1453-2271. 